\title{
Pengaruh Modal Psikologis dan Komitmen Organisasional terhadap Kinerja Guru Dimoderasi Gaya Kepemimpinan Transformasional
}

\author{
1) Amiluddin, 2) Mohammad Fauzan \\ Program Pasca Sarjana Universitas STIKUBANK Semarang \\ Email: amiluddin spd@yahoo.com
}

\begin{tabular}{l} 
Article Info \\
\hline Article History \\
Received: 2020-11-17 \\
Revised: 2021-01-05 \\
Published: 2021-01-18 \\
\\
Keywords: \\
Psychological Capital; \\
Organizational \\
Commitment, \\
Transformational \\
Leadership style; \\
Teacher performance.
\end{tabular}

\begin{abstract}
This study is about the effects of psychological capital and organizational commitment on teacher performance moderated transformational leadership style at SMK in Pemalang regency. The purpose of this study is to examine how the influence of psychological capital and organizational commitment on teacher performance moderated transformational leadership style. The population in this study are 133 SMK's teachers in Pemalang regency. The research data in this research is primary data which conducted by using questionnaire. The data analysis based on Moderation Regression Analisys (MRA) type quasi moderator. The results showed that psychological capital did not effect on the teacher performance. Organizational commitment have a positive effect on the teacher performance. Transformational leadership style have a positive effect on the teacher performance. Transformational leadership style did not moderate the influence of psychological capital to the teacher performance. Transformational leadership style did not moderate the influence of organizational commitment to the teacher performance.
\end{abstract}

\begin{tabular}{ll}
\hline Artikel Info & Abstrak \\
\hline Sejarah Artikel & Penelitian ini untuk meneliti pengaruh modal psikologis dan komitmen organisasional \\
Diterima: 2020-11-17 & terhadap kinerja guru dimoderasi gaya kepemimpinan transformasional pada SMK \\
Direvisi: 2021-01-05 & Negeri di Kabupaten Pemalang. Tujuan penelitian ini adalah untuk menguji \\
Dipublikasi: 2021-01-18 & $\begin{array}{l}\text { bagaimana pengaruh modal psikologis dan komitmen organisasional terhadap kinerja } \\
\text { guru dimoderasi gaya kepemimpinan transformasional. Populasi dalam penelitian ini }\end{array}$ \\
Kata kunci: & adalah guru-guru SMK Negeri di Kabupaten Pemalang yang berjumlah 133 orang. Data \\
Modal Psikologis; & penelitian adalah data primer yang diperoleh langsung dari responden dengan \\
Komitmen & kuesioner. Metode analisis data menggunakan Moderation Regression Analisys (MRA) \\
Organisasional; & tipe quasi moderator. Hasil penelitian menunjukkan bahwa modal psikologis tidak \\
Gaya Kepemimpian & berpengaruh terhadap kinerja guru. Komitmen organisasional berpengaruh positif \\
Transformasional; & terhadap kinerja guru. Gaya kepemimpinan transformasional berpengaruh positif \\
Kinerja Guru. & terhadap kinerja guru. Gaya kepemimpinan transformasional tidak memoderasi \\
& pengaruh terhadap modal psikologis dengan kinerja guru. Gaya kepemimpinan \\
& transformasional tidak memoderasi pengaruh terhadap komitmen organisasional \\
dengan kinerja guru.
\end{tabular}

\section{PENDAHULUAN}

Pembangunan nasional dalam bidang pendidikan adalah upaya mencerdaskan kehidupan bangsa dan meningkatkan kualitas manusia Indonesia yang beriman, bertakwa, dan berakhlak mulia serta menguasai ilmu pengetahuan, teknologi, dan seni dalam mewujudkan masyarakat yang maju, adil, makmur, dan beradab berdasarkan Pancasila dan Undang-Undang Dasar Negara Republik Indonesia Tahun 1945 (UU No. 14 Tahun 2005 tentang Guru dan Dosen). Guru adalah pendidik profesional dengan tugas utama mendidik, mengajar, membimbing, mengarahkan, melatih, menilai, dan mengevaluasi peserta didik pada pendidikan anak usia dini jalur pendidikan formal, pendidikan dasar, dan pendidikan menengah (UU No.14 tahun 2005).
Kinerja guru adalah kinerja yang terkait dengan pelaksanaan proses pembelajaran bagi guru mata pelajaran atau guru kelas, meliputi kegiatan merencanakan dan melaksanakan pembelajaran, mengevaluasi dan menilai, menganalisis hasil penilaian, dan melaksanakan tindak lanjut hasil penilaian, (Permendiknas No. 16 Tahun 2007). Kinerja guru akan baik jika guru telah melakukan unsur-unsur yang terdiri dari kesetiaan dan komitmen yang tinggi pada tugas mengajar, menguasai dan mengembangkan bahan pelajaran, kedisiplinan dalam mengajar dan tugas lainnya, kreativitas dalam pelaksanaan pengajaran, kerjasama dengan semua warga sekolah, kepemimpinan yang menjadi panutan siswa, kepribadian yang baik, jujur dan objektif dalam 
membimbing siswa, serta tanggung jawab terhadap tugasnya.

\section{a. Modal Psikologis}

Modal psikologis menurut Luthans, et al. (2007) dapat diartikan semacam modal sikap dan perilaku yang berperan besar dalam menentukan keberhasilan. Modal psikologis merupakan sebuh keadaan yang dapat dilatih dan dimiliki semua orang. Modal Psikologis, menurut Luthans, et al. (2007) adalah keadaan perkembangan psikologi individu yang positif, yang dicirikan oleh: selfefficacy, optimism, hope, dan resiliency.

\section{b. Komitmen Organisasional}

Komitmen organisasional didefinisikan oleh Durkin dan Bennet (1999) sebagai perasaan yang kuat dan erat dari seseorang terhadap tujuan dan nilai suatu organisasi dalam hubungannya dengan peran mereka terhadap upaya pencapaian tujuan dan nilai-nilai tersebut. Allen and Meyer (1990) mengajukan tiga bentuk komitmen organisasi yaitu: Komitmen afektif (affective commitment), komitmen kontinuan (continuance commitment), dan komitmen normatif (normative commitmen), Porter dalam Panggabean (2004) menyatakan bahwa Komitmen Organisasi adalah kuatnya pengenalan dan keterlibatan seseorang dalam suatu organisasi tertentu. Karyawan yang komit dengan organisasi mampu menunjukkan peningkatan efektivitas organisasi yang ditunjukkan lewat tingginya pencapaian kinerja kerja, kualitas pekerjaan, dan mengurangi keterlambatan kerja, ketidakhadiran, serta pergantian karyawan (Mathieu dan Zajac, Randall, dalam Juliandi, 2003). Makna komitmen organisasi adalah tingkat kepercayaan dan penerimaan tenaga kerja terhadap tujuan organisasi dan mempunyai keinginan untuk tetap ada di dalam organisasi yang pada akhirnya tergambar dalam statistik ketidakhadiran serta keluar masuk tenaga kerja/turnover (Mathis dan Jackson, 2001).

Luthans (2006) menyatakan Komitmen organisasi adalah: a) suatu keinginan yang kuat untuk menjadi anggota dari organisasi tertentu, b) keinginan untuk berusaha keras sesuai keinginan organisasi, dan c) suatu kepercayaan tertentu, dan penerimaan terhadap nilai-nilai dan tujan organisasi tersebut. Dengan kata lain komitmen organisasi adalah sikap yang merefleksikan loyalitas karyawan pada organisasi dan proses berkelanjutan dimana anggota organisasi mengekspresikan perhatiannya terhadap organisasi dan keberhasilan serta kemajuan yang berkelanjutan. Porter juga mendefinisikan komitmen organisasi sebagai kekuatan yang bersifat 46relatif dari individu dalam mengidentifikasikan keterlibatan dirinya sebagai bagian organisasi, yang ditandai dengan tiga hal, yaitu: a) Penerimaan terhadap nilai-nilai dan tujuan organisasi, b) Kesiapan dan kesediaan untuk berusaha dengan sungguh-sungguh atas nama organisasi, dan c) Keinginan mempertahankan keanggotaan di dalam organisasi menjadi bagian dari organisasi (Mowday, dalam Juliandi, 2003).

Menurut Meyer and Allen (1993) komitmen organisasional adalah sebuah keadaan psikologi yang mengkarakteriskan hubungan karyawan dengan organisasi atau implikasinya yang mempengaruhi apakah karyawan akan tetap bertahan dalam organisasi atau tidak, yang terindentifikasi dalam tiga komponen yaitu: komitmen afektif, komitmen kontinyu dan komitmen normatif.

Pengertian-pengertian di atas menunjukkan bahwa komitmen organisasi merupakan sikap tentang loyalitas tenaga kerja kepada organisasi mereka, dan sebuah proses terus menerus yang berlanjut dimana partisipan organisasi mengungkapkan perhatian untuk organisasi dan kesuksesan yang berkelanjutan. Manfaat dari komitmen yakni tenaga kerja dapat memberikan suatu kontribusi besar ke organisasi sebab mereka bertindak menuju keberhasilan tujuan organisasi. Para pekerja yang merasa terikat dengan organisasi, merasa senang untuk menjadi anggota organisasi, percaya akan organisasi dan memandang baik tentang organisasi, yang terwujud dalam perilaku mewakili organisasi dalam lingkungan luar organisasi, serta melakukan hal-hal terbaik untuk organisasi (Sutanto dalam Juliandi, 2003).

Curtis dan Wright (2001) mengemukakan bahwa komitmen didefinisikan sebagai kekuatan identifikasi individu yang berada dalam sebuah organisasi. Jika seseorang memiliki komitmen untuk organisasi, ia akan memiliki identifikasi yang kuat dengan organisasi, memiliki nilai-nilai keanggotaan, setuju dengan tujuan dan sistem nilai, kemungkinan akan tetap di dalamnya, dan akhirnya, siap untuk bekerja keras demi organisasinya. Lebih lanjut sikap loyalitas ini diindikasikan dengan tiga hal, yaitu: (1) keinginan kuat seseorang untuk tetap menjadi anggota organisasinya; (2) kemauan untuk mengerahkan usahanya untuk organisasinya; (3) keyakinan dan penerimaan yang kuat terhadap nilai-nilai dan tujuan organisasi. Komitmen organisasional akan membuat pekerja memberikan yang terbaik kepada organisasi tempat dia bekerja. Pekerja dengan komitmen yang tinggi akan lebih berorientasi pada kerja. Guru yang memiliki komitmen organisasi yang tinggi juga memiliki pandangan yang positif dan akan melakukan yang terbaik untuk kepentingan organisasi. Hal ini guru memiliki keinginan yang kuat untuk memberikan tenaga dan tanggung jawab yang lebih menyokong kesejahteraan dan keberhasilan organisasi temapatnya bekerja. 


\section{c. Gaya Kepemimpinan Transformasional}

Kepemimpinan (leadership) adalah kegiatan untuk mempengaruhi perilaku orang lain, atau seni mempengaruhi perilaku manusia, baik perseorangan maupun kelompok. Robbins (1993) mendefinisikan kepemimpinan sebagai kemampuan seseorang untuk mempengaruhi sebuah kelompok. Kepemimpinan sebagai proses mempengaruhi orang lain untuk mendukung pencapaian tujuan organisasi yang relevan. Luthans (2006) mendefinisikan kepemimpinan sebagai sekelompok proses, kepribadian, pemenuhan, perilaku tertentu, persuasi, wewenang, pencapaian tujuan, interaksi, perbedaan peran, inisiasi struktur, dan kombinasi dari dua atau lebih dari hal-hal tersebut. Seluruh kegiatan itu dapat disebut sebagai usaha mempengaruhi perasaan, pikiran dan tingkah laku orang lain kearah pencapaian suatu tujuan organisasi.

Gaya kepemimpinan adalah cara seorang pemimpin melaksanakan kegiatannya dalam upaya membimbing, memandu, mengarahkan, dan mengontrol pikiran, perasaan, atau perilaku seseorang atau sejumlah orang untuk mencapai tujuan tertentu. Luthan (2002) mendefinisikan gaya kepemimpinan (leadership styles) merupakan cara pimpinan untuk mempengaruhi orang lain/bawahannya sedemikian rupa sehingga orang tersebut mau melakukan kehendak pemimpin untuk mencapai tujuan organisasi meskipun secara pribadi hal tersebut mungkin tidak disenangi. Thoha (1986) gaya kepemimpinan merupakan norma perilaku yang digunakan oleh seseorang pada saat orang tersebut mencoba mempengaruhi orang lain seperti ia lihat.

Kepemimpinan transformasional merupakan kepemimpinan yang kharismatik, kepemimpinan yang menciptakan visi dan lingkungan yang memotivasi karyawan untuk berprestasi mencapai harapan. Burns (1978) telah membagi bahasan tentang kepemimpinan berdasarkan gaya kepemimpinannya menjadi 2 (dua) macam, yaitu kepemimpinan transformasional (Transformational Leadership) dan kepemim-pinan transaksional (Transctional Leadership). Bass dan Avolio (1994) membagi kepemimpinan transformasional menjadi 4 (empat) dimensi, yaitu idelized influence, intellectual stimulation, inspirational motivation, dan individual consideration

Konsep pemikiran model kepemimpinan transformasional (transformational leadership) mendapat perhatian yang cukup besar dari James MacGregor Burns sejak tahun 1978. Burns merupakan salah satu penggagas yang secara eksplisit mendefinisikan kepemimpinan transformasional. Burns (1978) menyatakan bahwa model kepemimpinan transformasional pada hakekatnya menekankan seorang pemimpin perlu memotivasi bawahannya untuk melakukan tanggung jawab mereka lebih dari yang mereka harapkan. Pemimpin transformasional harus mampu mendefinisikan, mengkomunikasikan dan mengartikulasikan visi organisasi dan bawahan harus menerima dan mengakui kredibilitas pemimpinnya.

Menurut Bass (1999 : 11) kepemimpinan transformasional mengartikula-sikan visi masa depan yang realistik, menstimulasi pengikut/ bawahan, dan menaruh perhatian pada perbedaan individual yang dimiliki bawahan. Pemimpin transformasional harus mempengaruhi bawahan melakukan tugas-tugas melebihi kepentingan dirinya sendiri demi kepentingan organisasi yang lebih besar. Kepemimpinan transformasional dapat memberikan dampak atau pengaruh kepada para bawahannya, sehingga terbentuk rasa percaya, rasa kagum dan rasa hormat.

Gaya Kepemimpinan transformasional merupakan suatu model kepemimpinan yang bertujuan untuk mendorong upaya ekstra (usaha lebih keras) guru untuk mencapai kinerja tinggi seperti yang diharapkan. Kepemimpinan transformasional pada prinsipnya memotivasi bawahan untuk berbuat lebih baik dari apa yang biasa dilakukan, dengan kata lain dapat meningkatkan kepercayaan atau keyakinan diri bawahan yang akan berpengaruh terhadap peningkatan kinerja guru.

\section{d. Kinerja Guru}

Istilah kinerja berasal dari kata kata job performance atau actual performance, yang berarti prestasi kerja atau prestasi sesungguhnya yang dicapai oleh seseorang. Sedangkan pengertian kinerja menurut Kamus Besar Bahasa Indonesia adalah: (1) sesuatu yang dicapai, (2) prestasi yang diperlihatkan, dan (3) kemampuan bekerja.

Kinerja (performance) menurut Drucker (2002 : 134) adalah tingkat prestasi atau hasil nyata yang dicapai dipergunakan untuk memperoleh suatu hasil positif. Kinerja juga didefinisikan sebagai keberhasilan personel dalam mewujudkan sasaran stratejik pada empat perspektif : keuangan, kostumer, proses serta pembelajaran dan pertumbuhan (Mulyadi, 2007: 363).

Hasibuan (2007:94) merumuskan kinerja atau prestasi kerja sebagai suatu hasil kerja yang dicapai seseorang dalam melaksanakan tugastugas yang dibebankan kepadanya yang didasarkan atas kecakapan, pengalaman kerja, dan kesungguhan serta waktu. Sentono (1999:2) mengatakan bahwa kinerja adalah hasil kerja yang dapat dicapai oleh seseorang atau sekelompok orang dalam suatu organisasi, sesuai dengan wewenang dan tanggung jawab masingmasing dalam rangka mencapai tujuan 
organisasi. Apabila kinerja tiap individu atau karyawan baik, maka diharapkan kinerja perusahaan akan baik pula. Rich (1997 : 118) menyatakan kinerja dianggap lebih produktivitas karena kinerja menyangkut perilaku alami yang dimiliki seseorang untuk bebas melakukan tindakan sesuai dengan keinginannya. Perilaku bebas untuk bertindak ini tetap tidak bisa dilepaskan dari syarat-syarat formal seorang karyawan untuk meningkatkan fungsi efektif suatu organisasi. Casio (1995 : 22) mengatakan bahwa kinerja merupakan prestasi karyawan dari tugas-tugas yang telah ditetapkan.

Kinerja guru merupakan hasil dari fungsi pekerjaan atau kegiatan tertentu yang di dalamnya terdiri dari tiga aspek, yaitu: kejelasan tugas atau pekerjaan yang menjadi tanggung jawabnya, kejelasan hasil yang diharapkan dari suatu pekerjaan atau fungsi, kejelasan waktu yang diperlukan untuk menyelesaikan suatu pekerjaan agar hasil yang diharapkan dapat terwujud (Timpe, 1992). Kinerja guru adalah kinerja yang terkait dengan pelaksanaan proses pembelajaran bagi guru mata pelajaran atau guru kelas, meliputi kegiatan merencanakan dan melaksanakan pembelajaran, mengevaluasi dan menilai, menganalisis hasil penilaian, dan melaksanakan tindak lanjut hasil penilaian, (Permendiknas No. 16 Tahun 2007). Kinerja guru akan baik jika guru telah melakukan unsur-unsur yang terdiri dari kesetiaan dan komitmen yang tinggi pada tugas mengajar, menguasai dan mengembangkan bahan pelajaran, kedisiplinan dalam mengajar dan tugas lainnya, kreativitas dalam pelaksanaan pengajaran, kerjasama dengan semua warga sekolah, kepemimpinan yang menjadi panutan siswa, kepribadian yang baik, jujur dan objektif dalam membimbing siswa, serta tanggung jawab terhadap tugasnya.

Berdasarkan definisi kinerja yang dikemukakan oleh beberapa ahli di atas, dapat disimpulkan bahwa kinerja adalah hasil kerja atau prestasi yang dicapai oleh seseorang, yang dinilai berdasarkan kualitas dan kuantitasnya, sesuai dengan tugas dan tanggung jawab yang dibebankan kepadanya dalam rangka mencapai tujuan dari pendidikan sekolah. Dengan demikian, kinerja guru berarti hasil kerja / prestasi seorang guru dalam mengemban tugasnya sebagai seorang pendidik agar dapat memenuhi tujuan dari sekolah tempatnya bekerja.

\section{e. Model Teoritik}

Berdasarkan telaah pustaka atas kajian teoriteori dan penelitian-penelitian terdahulu, maka disusun model penelitian yaitu "Pengaruh Modal Psikologis dan Komitmen Organisasional terhadap Kinerja Guru dimoderasi Gaya Kepe mimpinan Transformasional" dapat digambarkan sebagai berikut

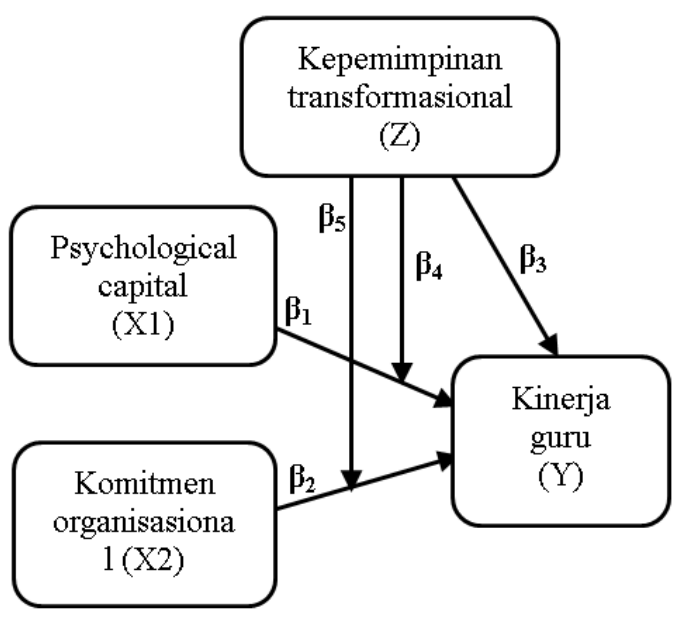

Gambar 1. Model Grais dalam Penelitian

\section{f. Perumusan Hipotesis}

\section{Pengaruh Modal Psikologis terhadap Kinerja Guru}

Modal Psikologis menurut pendapat dari Luthans, Yousef dan Avolio (2007) adalah pernyataan psikologis individu yang dikarakteristikan oleh 4 hal, yaitu memiliki kepercayaan diri yang tinggi dalam mengahadapi tantangan (1), memiliki kondisi atau motivasi positif akan tercapainya kesuksesan (2), memiliki atribusi positif atau optimism yang tinggi akan tercapainya kesuksesan baik saat ini ataupun di masa mendatang (3), serta memiliki psikologis positif yang dapat mendorong sesorang akan bangkit dari kegagalan maupun tambahan tugas yang diberikan (4). Dalam sebuah organisasi sekolah modal psikologis sangat dibutuhkan untuk mengembangkan diri seseorang. Guru yang memiliki perilaku psikologis yang positif diharapkan mampu menghasilkan kinerja yang optimal. Dengan kinerja yang optimal, maka tujuan dari organisasi sekolah akan tercapai. Tercapainya tujuan organisasi sekolah tentunya akan memberikan dampak positif terhadap peningkatan pelayanan yang diberikan kepada masyarakat.

Luthans, Avolio, Walumbwa, and Li (2005) melakukan penelitian pada tiga pabrik di RRC tentang psychological capital terhadap kinerja pekerja Cina, menjelaskan bahwa modal psikologis berpengaruh positif terhadap kinerja pekerja Cina. Berdasarkan konsep dan penelitian terdahulu, hipotesis pertama (H1) dapat dirumuskan sebagai berikut:

H1: Modal psikologis berpengaruh positif dan signifikan terhadap kinerja guru.

\section{Pengaruh Komitmen Organisasional terhadap Kinerja Guru}

Komitmen organisasional adalah sikap yang merefleksikan loyalitas karyawan pada organisasi dan proses berkelanjutan dimana 
anggota organisasi mengekspresikan perha tiannya terhadap organisasi dan kebe rhasilan serta kemajuan yang berkelanjutan (Allen and Meyer, 1990). Aspek kinerja dalam pelaksanaan tugas utama guru adalah kinerja yang terkait dengan pelaksanaan proses pembelajaran bagi guru mata pelajaran atau guru kelas, meliputi kegiatan merencanakan dan melaksanakan pembelajaran, mengevaluasi dan menilai, menganalisis hasil penilaian, dan melaksanakan tindak lanjut hasil penilaian. Kinerja guru akan baik jika guru telah melakukan unsur-unsur yang terdiri dari kesetiaan dan komitmen yang tinggi pada tugas mengajar.

Komitmen Organisasional ditunjukkan dalam sikap penerimaan keyakinan yang kuat terhadap nilai-nilai dan tujuan sebuah organisasi, begitu juga adanya dorongan yang kuat untuk mempertahankan keanggotaan dalam organisasi demi tercapainya tujuan organisasi. Dengan komitmen organisasional yang tinggi dapat meningkatkan kinerja guru dalam melaksanakan tugas pokok dan fungsinya. Adnan (2013) dalam penelitiannya menyatakan terdapat pengaruh positif yang signifikan komitmen organisasi terhadap kinerja. Berdasarkan konsep dan penelitian terdahulu, maka hipotesis kedua (H2) dapat dirumuskan sebagai berikut:

H2: Komitmen organisasional berpengaruh positif dan signifikan terhadap kinerja guru.

\section{Pengaruh Gaya Kepemimpinan Transforma- sional terhadap Kinerja Guru}

Gaya kepemimpinan transformasional pada hakekatnya menekankan seorang pemimpin perlu memotivasi para bawahannya untuk melakukan tanggung jawab mereka lebih dari yang mereka harapkan (Burns, 1978). Peran seorang pemimpin sangat dibutuhkan, dan kepemimpinan yang efektif menjadi syarat utama. Dalam kepemimpinan transformasional terjadi umpan balik yang positif antara bawahan dan pimpinan. Kepemimpinan transformasional juga melibatkan pengem bangan hubungan yang lebih dekat antara pemimpin dengan bawahan. Dengan kepemimpinan transformasional, pemimpin membantu bawahan untuk melihat kepentingan yang lebih penting daripada kepentingan mereka sendiri demi misi dan visi organisasi dan juga untuk mencapai kinerja yang maksimal. Hubungan antara gaya kepemimpinan transformasional dan kinerja guru merupakan suatu hal yang pasti dan disadari oleh kedua belah pihak, baik dari pemimpin maupun guru. Dengan gaya kepemimpinan transformasional yang efektif dapat meningkatkan kinerja guru.
Paracha, Qomar, Mirza, and Waqas (2012) dalam penelitiannya menjelaskan bahwa kepemimpinan transformasional berpengaruh positif dan signifikan terhadap kinerja karyawan. Berdasarkan konsep dan penelitian terdahulu, hipotesis ketiga (H3) dapat dirumuskan sebagai berikut :

H3: Gaya kepemimpinan transformasional berpengaruh positif dan signifikan terhadap kinerja guru.

\section{Pengaruh Modal Psikologis terhadap Kinerja Guru dimoderasi Gaya Kepemimpinan Transformasional}

Modal Psikologis, menurut Luthans, et al. (2007) adalah keadaan perkembangan psikologi individu yang positif. Psychological capital merupakan sebuh state (keadaan) yang dapat dilatih dan dimiliki semua orang (Christy, 2013).

Gaya kepemimpinan trasformasional merupakan perilaku dan strategi, yang sering diterapkan seorang pemimpin ketika ia mencoba mempengaruhi kinerja bawahannya. Untuk memelihara kinerja yang optimal, seorang pemimpin harus menanamkan modal psikologis positif pada bawahannya. Seorang pemimpin dalam hal ini Kepala Sekolah dalam memelihara kinerja guru yang baik, maka ia perlu menanamkan modal psikologis positif pada bawahannya. Dengan demikian, gaya kepemimpinan trasformasional akan memperkuat pengaruh modal psikologis terhadap kinerja guru.

Venkatesh and Blaskovich (2012) hasil penelitiannya menjelaskan bahwa modal psikologis berpengaruh positif dan signifikan terhadap kinerja karyawan. Berdasarkan konsep dan penelitian terdahulu, hipotesis keempat (H4) dapat dirumuskan sebagai berikut:

H4: Gaya kepemimpinan transformasional memperkuat pengaruh terhadap modal psikologis dengan kinerja guru

5. Pengaruh Komitmen Organisasional terhadap Kinerja Guru dimoderasi Gaya Kepemimpinan Transformasional

Gaya kepemimpinan merupakan norma perilaku yang digunakan oleh seseorang pada saat orang tersebut mencoba mempengaruhi orang lain seperti ia lihat (Thoha, 1986). Gaya kepemimpinan trasformasional merupakan perilaku dan strategi, yang sering diterapkan seorang pemimpin ketika ia mencoba mempengaruhi kinerja bawahannya. Untuk memelihara kinerja yang optimal pada bawahannya, seorang pemimpin harus menjaga bawahan dari sikap penerimaan keyakinan yang kuat terhadap nilai-nilai dan tujuan organisasi, juga pemimpin harus 
mempertahankan keanggotaan bawahan dalam organisasi demi tercapainya tujuan organisasi. Seorang pemimpin dalam hal ini Kepala sekolah dalam memelihara kinerja guru yang baik, maka ia perlu menjaga komitmen organisasional guru yang baik pula. Dengan demikian, gaya kepemimpinan trasformasional akan memperkuat pengaruh komitmen organisasional terhadap kinerja guru.

Taurisa dan Ratnawati (2012) dalam peneliti-annya menjelaskan komitmen organisasional berpengaruh positif dan signifikan terhadap kinerja karyawan. Berdasarkan konsep dan penelitian terdahulu, maka hipotesis kelima (H5) dapat dirumuskan sebagai berikut :

H5: Gaya kepemimpinan transformasional memperkuat pengaruh terhadap komitmen organisasional dengan kinerja guru.

\section{METODE PENELITIAN \\ a) Populasi}

Populasi dalam penelitian ini adalah semua guru SMK Negeri di Kabupaten Pemalang kelompok teknologi dan rekayasa berjumlah 145 orang dengan data kuesioner yang dapat diolah sebanyak 133 yang tersebar di 3 SMK Negeri di Kabupaten Pemalang.

\section{b) Metode Pengumpulan Data}

Metode pengumpulan data penelitian menggunakan kuesioner. Penentuan skor jawaban responden untuk data primer dilakukan dengan menggunakan skala Likert dalam interval 1 sampai 5. Pengukuran ini menggunakan pertanyaanpertanyaan dan di dalam menanggapi pertanyaan tersebut, subyek memilih salah satu dari lima alternatif jawaban sesuai dengan keadaan subyek. Alternatif jawaban tersebut meliputi sangat tidak setuju (STS) dengan nilai 1 (satu), tidak setuju (TS) dengan nilai 2 (dua), netral $(\mathrm{N})$ dengan nilai 3 (tiga), setuju (S) dengan nilai 4 (empat), dan sangat setuju (SS) dengan nilai 5 (lima).

\section{c) Definisi Konsep dan Operasional}

Variabel bebas dalam penelitian ini adalah Modal psikologis (X1) dan Komitmen Organisasional (X2) dan variabel terikat adalah Kinerja Guru (Y). Sedangkan variabel moderasi adalah Gaya Kepemimpinan Transformasional (Z).

1. Modal psikologis adalah keadaan perkembangan psikologi individu yang positif, yang dicirikan oleh self-efficacy, optimism, hope, dan resiliency.

2. Komitmen organisasional adalah sikap yang merefleksikan loyalitas karyawan pada organisasi dan proses berkelanjutan dimana anggota organisasi mengekspresikan perhatiannya terhadap organisasi dan keberhasilan serta kemajuan yang berkela-njutan.

3. Gaya kepemimpinan transformasional pada hakekatnya menekankan seorang pemimpin perlu memotivasi para bawahannya untuk melakukan tanggung jawab mereka lebih dari yang mereka harapkan.

4. Kinerja guru adalah hasil dari fungsi pelaksanaan proses pembelajaran bagi guru meliputi kegiatan merencanakan dan melaksanakan pembelajaran, mengevaluasi dan menilai, menganalisis hasil penilaian, dan melaksanakan tindak lanjut hasil penilaian.

\section{HASIL DAN PEMBAHASAN}

\section{a) Hasil Penelitian}

\section{Uji Validitas}

Pengujian validitas dikatakan instrumen memenuhi kecukupan sampel apabila memiliki nilai KMO lebih dari 0,5 dan dikatakan valid apabila memiliki nilai loading factor lebih dari 0,4. Untuk menguji validitas dari masing-masing butir pertanyaan tersebut digunakan analisis faktor dengan hasil sebagaimana diuraikan berikut ini.

Berdasarkan hasil pengujian diperoleh nilai KMO untuk masing-masing variabel modal psikologis, komitmen organisasional, gaya kepemimpinan transformasional dan kinerja guru adalah $>0,5$ dengan tingkat signifikan 0,000 yang berarti kecukupan sampel terpenuhi. Sedangkan melalui pengujian validitas dari kuesioner variabel modal psikologis, komitmen organisasional, gaya kepemimpinan transformasional dan kinerja guru memiliki nilai loading factor $>0,4$ sehingga dapat disimpulkan bahwa seluruh butir pernyataan dalam kuesioner dikatakan valid.

\section{Uji Reliabilitas}

Uji reliabilitas digunakan untuk mengetahui sejauh mana data dapat memberikan hasil yang konsisten atau stabil dari waktu ke waktu bila dilakukan pengukuran kembali terhadap obyek atau responden. Suatu kontruk atau variabel dikatakan reliabel jika memberikan nilai cronbach alpha $>0,7$.

Tabel 1. Hasil Uji Reliabilitas

\begin{tabular}{llll}
\hline Variabel & $\begin{array}{l}\text { Cronbach } \\
\text { Alpha }\end{array}$ & $\begin{array}{l}\text { Keten- } \\
\text { tuan }\end{array}$ & $\begin{array}{l}\text { Kete- } \\
\text { rangan }\end{array}$ \\
\cline { 1 - 2 } Psychological capital & 0,921 & & Reliabel \\
\cline { 1 - 2 } $\begin{array}{l}\text { Komitmen } \\
\text { organisasional }\end{array}$ & 0,930 & & Reliabel \\
\cline { 1 - 2 } $\begin{array}{l}\text { Gaya kepemimpian } \\
\text { transformasional }\end{array}$ & 0,944 & & Reliabel \\
\hline Kinerja guru & 0,928 & & Reliabel \\
\hline
\end{tabular}

\section{Uji Normalitas}

Hasil uji normalitas error (residual) menunjukkan besaran Asymp. Sig. (2-tailed) pada uji Kolmogorov-smirnov Z adalah $0,438>0,05$. 


\section{Uji Heteroskedastisitas}

Hasil uji Glejzer menunjukkan nilai variabel modal psikologis sebesar 0,233; komitmen organisasional sebesar 0,082 ; gaya kepemimpinan transformasional sebesar 0,338; selisih mutlak psy cap dan kepemimpinan transformasional (moderat_1) sebesar 0,672; dan selisih mutlak komitmen organisasional dan kepemimpinan transformasional (moderat_2) sebesar 0,310. Hal ini berarti semua variabel mempunyai nilai signifikan lebih dari 0,05 sehingga semua variabel tidak terjadi heteroskedastisitas.

\section{Uji Koefisien Determinasi}

Hasil uji determinasi menunjukkan nilai adjusted $\mathrm{R}$ square sebesar 0,489. Hal ini berarti $48,9 \%$ perubahan dari variabel kinerja guru dapat dijelaskan oleh varibel modal psikologis, komitmen organisasional, kepemimpinan transformasional serta moderasi_1 dan moderasi_2. Sedangkan sisanya sebesar $51,1 \%$ dijelaskan oleh variabel lain di luar model penelitian.

\section{Uji F}

Hasil uji $F$ menunjukkan nilai $(F=26.305$; sig $=0,000<0,05)$, maka model yang digunakan memenuhi persyaratan Goodness of Fit.

\section{b) Pembahasan}

\section{Pengujian Hipotesis 1}

Hasil pengujian hipotesis 1 menunjukkan bahwa modal psikologis tidak berpengaruh terhadap kinerja guru $(\beta=0,175$, sig $=0,116>$ $0,05)$. Berdasarkan hasil pengujian tersebut, maka hipotesis 1 (H1) yang dirumuskan bahwa modal psikologis berpengaruh positif dan signifikan terhadap kinerja guru, ditolak.

Hasil penelitian ini memperkuat temuan penelitian Hendarman (2008), dan hasil temuan ini bertentangan dengan penelitian Luthans, Avolio and Li (2005); Venkatesh and Blaskovich (2012).

\section{Pengujian Hipotesis 2}

Hasil pengujian menunjukkan bahwa komitmen organisasional mempunyai pengaruh positif terhadap kinerja guru $(\beta=$ 0,239 , sig $=0,02<0,05$ ). Berdasarkan hasil pengujian tersebut, maka hipotesis $2(\mathrm{H} 2)$ yang dirumuskan bahwa komitmen organisasional berpengaruh positif dan signifikan terhadap kinerja guru, diterima.

Temuan ini mendukung hasil penelitian (Adnan, 2013; Thamrin, 2012; Taurisa dan Ratnawati, 2012; Yuleova, 2013; Suwardi dan Utomo, 2011).

\section{Pengujian Hipotesis 3}

Hasil pengujian menunjukkan bahwa gaya kepemimpinan transformasional mempunyai pengaruh positif terhadap kinerja guru $(\beta=$ 0,405 , sig $=0,000<0,05$ ). Berdasarkan hasil pengujian tersebut, maka hipotesis 3 (H3) yang dirumuskan bahwa gaya kepemimpinan transformasional berpengaruh positif dan signifikan terhadap kinerja guru, diterima.

Hal ini sesuai dengan hasil penelitian (Paracha, et al, 2012; Nugroho, 2011; Apriana, dkk, 2013; Munawaroh, 2011; Makmuriana, dkk, 2014; Taruno dkk, 2012).

\section{Pengujian Hipotesis 4}

Hasil pengujian menunjukkan bahwa gaya kepemimpinan transformasional tidak memoderasit pengaruh terhadap modal psikologis dengan kinerja guru $(\beta=-0,055$, sig $=0,546>0,05)$. Hasil tersebut dapat dimaknai bahwa gaya kepemimpinan transformasional tidak memoderasi pengaruh modal psikologis dengan kinerja guru. Berdasarkan hasil pengujian tersebut, maka hipotesis 4 (H4) yang dirumuskan bahwa gaya kepemimpinan transformasional memperkuat pengaruh terhadap modal psikologis dengan kinerja guru, ditolak.

Berdasarkan hasil uji regresi dan deskripsi variabel, kondisi empiris ini terjadi karena sebagian besar guru menganggap bahwa gaya kepemimpinan transformasional tidak dapat memperkuat pengaruh terhadap modal psikologis dengan kinerja guru secara berkelanjutan. Gaya kepemimpinan adalah cara seorang pemimpin melaksanakan kegiatannya dalam upaya membimbing, memandu, mengarahkan, dan mengontrol pikiran, perasaan, atau perilaku seseorang atau sejumlah orang untuk mencapai tujuan tertentu. Dalam meningkatkan kinerja guru diperlukan peranan seorang pemimpin yang mempunyai modal psikologis. Modal psikologis dapat diartikan semacam modal sikap dan perilaku yang berperan besar dalam menentukan keberhasilan.

Seorang kepala sekolah tidak dapat dijadikan ukuran untuk menjadikan anak buahnya memiliki modal psikologis yang tinggi, karena modal psikologis adalah sebuah perkembangan jiwa yang akan membentuk sebuah karakter pada diri seseorang, yang tidak bisa secara langsung dipengaruhi oleh faktor luar terutama seorang kepala sekolah.

\section{Pengujian Hipotesis 5}

Hasil pengujian menunjukkan bahwa gaya kepemimpinan transformasional tidak memoderasi pengaruh terhadap komitmen organisasional dengan kinerja guru $(\beta=0,123$, sig $=$ $0,124>0,05)$. Berdasarkan hasil pengujian tersebut, maka hipotesis 5 (H5) yang dirumuskan bahwa gaya kepemimpinan transformasional memperkuat pengaruh 
terhadap komitmen organisasional dengan kinerja guru, ditolak.

Berdasarkan hasil uji regresi dan deskripsi variabel, kondisi empiris ini terjadi karena sebagian besar guru menganggap bahwa gaya kepemimpinan transformasional tidak mempengaruhi komitmen organisaional dalam peningkatan kinerja. Peran gaya kepemimpinan transformasional tidak berhasil memperkuat pengaruh komitmen organisasional terhadap kinerja guru. Komitmen organisasional yang semula pada hipotesis 2 (H2) berpengaruh positif dan signifikan terhadap kinerja guru, setelah berinteraksi dengan gaya kepemimpinan transformasional, gaya kepemimpinan transforma sional tidak memoderasi pengaruh terhadap komitmen organisasional dengan kinerja guru. Gaya kepemimpinan adalah perilaku dan strategi, yang sering diterapkan seorang pemimpin ketika ia mencoba mempengaruhi kinerja bawahannya. Untuk menjaga kinerja yang baik pada anak buahnya seorang pemimpin harus mampu menjaga komitmen organisasional yang baik pula. Sehingga dengan komitmen organisasi yang tinggi maka kinerja guru juga akan tinggi.

Dalam penelitian ini sekolah negeri yang diteliti merupakan sekolah baru yang belum mapan, sehingga guru-gurunya masih mencari bentuk komitmen organisasional apa yang cocok. Sekolah baru yang diteliti juga menerima banyak guru dari berbagai sekolah baik negeri maupun swasta, tentunya mereka membawa kebiasaan-kebiasaan di sekolah lama. Selain itu, pada saat penyebaran kuesioner dilakukan pada masa transisi kepemimpinan baru. Pemimpin yang baru dalam hal ini kepala sekolah baru belum sepenuhnya memberikan pengaruh positif terhadap anak buahnya. Para guru masih terbiasa dengan pola kepemimpinan kepala sekolah yang lama sehingga dalam meningkatkan kinerja guru sosok kepala sekolah lamalah yang sangat berpengaruh daripada kepala sekolah yang baru.

\section{SIMPULAN DAN SARAN}

\section{A. Simpulan}

1. Modal psikologis tidak berpengaruh signifikan terhadap kinerja guru.

2. Komitmen organisasional berpengaruh positif dan signifikan terhadap kinerja guru.

3. Gaya kepemimpinan transformasional berpen-garuh positif dan signifikan terhadap kinerja guru.

4. Gaya kepemimpinan transformasional tidak memoderasi pengaruh terhadap modal psikologis dengan kinerja guru.

5. Gaya kepemimpinan transformasional tidak memoderasi pengaruh terhadap komitmen organisasional dengan kinerja guru.

\section{B. Saran}

Penelitian lanjutan agar dapat mempertimbangkan Keterbatasan penelitian ini antara lain terletak pada hasil uji koefisien determinasi (Adjusted R Square) dengan nilai 0,489 artinya hanya 48,9\% kemampuan variabel independen (modal psikologis, komitmen organisasional, gaya kepemimpinan transformasional serta hasil moderasi_1 dan moderasi_2) dalam menjelaskan setiap perubahan variabel dependen (kinerja guru).

\section{DAFTAR RUJUKAN}

Aditya, Pitra Yusuf \& Rini Nugraheni (2014). Pengaruh Allen, N. J. and Meyer, J. P. (1991). A ThreeComponent Conceptualization of Organizational Commitment, Human Resource Management Review, Vol 1, No 1, pp.61-89.

Allen, N. J., and Meyer, J. P. (1990). The measurement and antecedents of affective, continuance and normative commitment to the organization. Journal of Occupational Psychology, 63, 1-18.

Apriana, I P. A. P., Natajaya, I N., Yudana, I M. (2013). Kontribusi Gaya Kepemimpinan Transformasional, Iklim Kerja, dan Kecerdasan Emosional terhadap Kinerja guru di SMA Negeri 1 Mengwi. e-Journal Program Pascasarjana Universitas Pendidikan Ganesha Program Studi Administrasi Pendidikan, (Volume 4 Tahun 2013).

Avey, B. J., F. Luthans, and C. M. Youssef. (2009). The additive value of positive psychological capital in predicting work attitudes and behaviors. Journal of Management 20 (10): 1-22.

Bass, B. M. (1999). Two Decades of Research and Development in Transformational Leadership. European Journal of Work and Organizational Psychology, 8 (1), 9-32.

Bogler, R. (2001). The Influence of Leadership Style on Teacher Job Satisfaction. Educational Administration Quarterly, Vol. 37 No. 5, 662-683.

Burns, J. M. (1978). Leadership, Harper and Row, New York. European Journal of Work and Organizational Psychology. 8(1), 9-32.

Christy. (2013). Psychological Capital, http://psikologi.tarumanagara.ac.id/ news_ media/read/media_articles/psychologicalcapital-christy, di download tgl 10 Januari 2015.

Curtis, S., and Wright, D. (2001). Retaining employees - the fast track to commitment, Management Research News, Vol 24, No 8, pp. 59-64.

Durkin, M., and Bennet, H. (1999). Employee commitment in retail banking: identifying and exploring hidden dangers, The International Journal of Bank Marketing, Vol 17, No 3, pp. 124137.

Gadot, E. (2006). Leadership style, organizational politics, and employees' performance An 
empirical examination of two competing models, Leadership style, 36(5), 661-683.

Handayani, W. (2008). Dampak Komitmen Organisasi, Self Efficacy terhadap Konflik Peran dan Kinerja karyawan PT. HM Sampoerna, Tbk di Surabaya, Jurnal Riset dan Bisnis, Vol. 8 No. 2, September 2008.

Hasibuan, Melayu. (2005). Manajemen Sumber Daya Manusia, Jakarta: PT Bumi Aksara.

Imam Ghozali. (2012). Aplikasi Multivariat Dengan Program IBM SPSS 20, Badan Penerbit Universitas Diponegoro, Semarang.

Luthans, F., Avolio, B. J, Avey, J. B., \& Norman, S. M. (2007). Positive Psychological Capital: Measurement and relationship with performance and satisfaction. Personal Psychologi, 60, pp. 541572.

Luthans, F., Avolio, B. J., Walumbwa, F. O., \& Li W. (2005). The Psychological Capital of Chinese Workers: Exploring the Relationship with Performance, Management and Organization Review 1:2, 249-271, 1740-8776.

Luthans, F., Norman, S.M., Avolio, J.B., \& Avey, J.B. (2008). The mediating role of psychological capital in the supportive organizational climate employee performance relationship. Journal of Organizational Behavior, 29, 219-238.

Marks, H. M., \& Printy, S. M. (2003). Principal Leadership and School Performance: An Integration of Transformational and Instructional Leadership. Educational Administration Quartterly, Vol. 39, No. 3 (August 2003) 370-397.

Meyer, J. P., Allen, N. J., \& Smit, C. A. (1993). Commitmen to organizational and occupation: Extension and test of a three component conceptualization. Journal of Applied Psychology, 78(4), 538-551.

Mufarroh;Sutrisno,T., Purnomosidhi. (2013). Pengaruh Budaya Organisasi, Komitmen Organisasi, Gaya Kepemimpinan, dan Kompetensi Terhadap kinerja Pemerintahan Daerah (Studi Empiris pada Kabupaten Bangkalan). Jurnal Infestasi, Vol. 9 No. 2 Desember 2013, Hal. 123-136, http:// infestasi.trunojoyo.ac.idadmindownload.phpid=1 46, 16-02-2015.

Nahid Sharifi, Badri Shahtalebi. (2014). The Relationship Between Dimensions of Psychological Capital With Organizational Commitment Studied: Staffs of General Directorate of Education of Isfahan, Kuwat chapter of Arabian Journal of Businnes and Management Review, Vol. 3, No. 11a, July 2014.
Paracha, M.U., Qamar, A., Mirza, A., Hasan, I., \& Waqas, H. (2012). Impact of Leadership Style (Transformational \& Transactional Leadership) On Employee Performance \& Mediating Role of Job Satisfaction" Study of Private School (Educator) In Pakistan. Global Journal of Management and Business Research. Volume 12 Issue 4 Version 1.0 March 2012

Peraturan Menteri Pendidikan Nasional RI No. 16 Tahun 2007 tentang Standar Kualifikasi Akademik dan Kompetensi Guru.

Peterson, Suzanne J., Fred Luthans, Bruce J Avolio, Fred O.W., Zhen Z. (2011). Psychological Capital and Employee Performance : A Latent Growth Modelling Approach. 64: 427-450.

Prasada, D., Sunarsi, D., \& Teriyan, A. (2020). Pengaruh Etos Kerja Dan Kompensasi Terhadap Komitmen Organisasi Pada DHL Logistic Di Jakarta. JENIUS (Jurnal Ilmiah Manajemen Sumber Daya Manusia), 4(1), 51-60.

Puspasari, D. (2010). Pengaruh Stres Kerja, Motivasi Kerja, dan Komitmen Organisasi Sekolah terhadap Kinerja Guru Ekonomi di Sekolah Menengah Atas Sekota Malang. Tesis, Universitas Negeri Malang, http://journal.um.ac.id/index.php/ekonomibisnis/article/view/2664.

Ronit Bogler \& Anit Somech (2004). Influence of teacher empowerment on teachers' organizational commitment, professional commitment and organizational citizenship behavior in schools. Journal Teaching and Teacher Education, 20 (2004) 277-289.

Rowold, J., \& Schlotz, W. (2009). Transformational and Transactional Leadership and Followers' Chronic Stress. Leadership Review, 9, 35-48.

Rozi, A., \& Sunarsi, D. (2020). The Influence of Motivation and Work Experience on Employee Performance at PT. Yamaha Saka Motor in South Tangerang. Jurnal Office, 5(2), 65-74.

Sunarsi, D. (2014). Pengaruh Gaya Kepemimpinan, Motivasi dan Disiplin Kerja Terhadap Kinerja Pendidik (Doctoral dissertation, Universitas Pamulang).

Sunarsi, D. (2016, October). Pengaruh Minat, Motivasi Dan Kecerdasan Kognitif Terhadap Prestasi Belajar (Studi Kasus Pada Mahasiswa Program Studi S-1 Manajemen. Fakultas Ekonomi. Universitas Pamulang. Thn. Akademik 20152016). In Proceedings (Vol. 1, No. 1).

Supendy, R., Setiawan, M., dan Troena, E. A. (2012). Pengaruh Kepemimpinan terhadap Motivasi dan Kinerja Karyawan serta Implikasinya terhadap Kepuasan Kerja (Studi pada Bank Pembangunan Daerah (BPD) Sulawesi Tenggara). Jurnal Aplikasi Manajemen, Volume 10, Nomor 2, Juni 2012. 
Supriyadi, D., Syafitri, L. N. H., Widodo, S. F. A., Wahidi, R., Arinta, Y. N., Nabhan, F., ... \& Cahyono, Y. (2020). Innovation And Authentic Leadership Of Islamic University Lectures In Faculty Pharmacy Faculty: What Is The Role of Psychological Capital?. Systematic Reviews in Pharmacy, 11(8), 383-393.

Suwardi dan Utomo, J. (2011). Pengaruh Motivasi Kerja, Kepuasan Kerja, dan Komitmen Organisasional Terhadap Kinerja Pegawai (Studi pada Pegawai Setda Kabupaten Pati). Analisis Manajemen, Vol. 5 No. 1 Juli 2011, ISSN: 144111799, http://jurnal.umk.ac.idindex. PhpJAMarticle download1615, 20-01-15.

Taruno, FX. S. C., Thoyib, A., Zain, D., dan Rahayu, M. (2012). Pengaruh Gaya Kepemimpinan terhadap Kinerja Dosen dengan Kepuasan Kerja dan Motivasi Kerja sebagai Mediator (Studi pada Perguruan Tinggi Swasta di Jayapura). Jurnal Aplikasi Manajemen, Volume 10, Nomor 3, september 2012.
Taurisa, C.M. dan Ratnawati, I. (2012). Analisis Pengaruh Budaya Organisasi dan Kepuasan Kerja terhadap Komitmen Organisasional dalam Meningkatkan Kinerja Karyawan (Studi pada PT. Sido Muncul Kaligawe Semarang). Jurnal Bisnis dan Ekonomi, Vol. 19, No. 2, September 2012, Hal. 170 - 187, ISSN: 1412-3126.

Thamrin, H. M. (2012), The Influence of Transformational Leadership and Organizational Commitment on Job Satisfaction and Employee Performance. International Journal of Innovation, Management and Technology, Vol. 3, No. 5, October 2012.

Thoha, M. (1986). Perilaku Organisasi Konsep Dasar dan Aplikasinya, Rajawali, Jakarta.

Undang-Undang Republik Indonesia No. 14 Tahun 2005 Tentang Guru dan Dosen.

Venkatesh, R., \& Blaskovich, J. (2012). The Mediating Effect of Psychological Capital on the Budget Participation-Job Performance Relattionship. Journal of Management Accounting Reasearch. Vol. 24. pp. 159 - 175. 